\title{
CAPITAL GAINS HOLDING PERIODS AND EQUITY TRADING: EVIDENCE FROM THE 1998 ACT
}

\author{
Jennifer L. Blouin \\ Jana Smith Raedy \\ Douglas A. Shackelford \\ Working Paper 7827 \\ http://www.nber.org/papers/w7827
NATIONAL BUREAU OF ECONOMIC RESEARCH 1050 Massachusetts Avenue
Cambridge, MA 02138

August 2000

We appreciate the helpful comments from John Hand, Mark Lang, Wayne Landsman, Ed Maydew, and workshop participants at the University of North Carolina. The views expressed herein are those of the authors and not necessarily those of the National Bureau of Economic Research.

(C) 2000 by Jennifer L. Blouin, Jana Smith Raedy, and Douglas A. Shackelford. All rights reserved. Short sections of text, not to exceed two paragraphs, may be quoted without explicit permission provided that full credit, including $\odot$ notice, is given to the source. 
Capital Gains Holding Periods and Equity Trading: Evidence from the 1998 Tax Act Jennifer L. Blouin, Jana Smith Raedy, and Douglas A. Shackelford

NBER Working Paper No. 7827

August 2000

JEL No. H24, G12, G14, G18, H22

\section{ABSTRACT}

This paper exploits an unusually powerful setting to explore a choice many individual investors face regularly - the decision to sell today or postpone selling until lower rates are available in the future. We examine trading volume and stock returns around the 1998 reduction in the holding period required for individual investors to receive the most favorable long-term capital gains tax rate. For firms whose initial public shareholders were affected by the legislation, we find trading volume increasing and share returns decreasing in past price performance on the day the legislation was publicly disclosed. The results are consistent with capital gains holding periods distorting markets sufficiently that if investors are permitted to liquidate appreciated positions at favorable rates, enough will sell immediately to move prices. To our knowledge, this is the first study linking trading volume and security prices to a change in capital gains holding periods.

Jennifer L. Blouin

Kenan-Flagler Business School University of North Carolina Campus Box 3490, McColl Building

Chapel Hill, NC 27599-3490

Douglas A. Shackelford

Kenan-Flagler Business School

University of North Carolina

Campus Box 3490, McColl Building

Chapel Hill, NC 27599-3490

and NBER

doug_shack@unc.edu
Jana Smith Raedy

Kenan-Flagler Business School

University of North Carolina

Campus Box 3490, McColl Building

Chapel Hill, NC 27599-3490 


\section{Capital Gains Holding Periods and Equity Trading: Evidence from the 1998 Tax Act}

\section{Introduction}

Individuals generally face lower marginal income tax rates if they defer selling appreciated investments. For example, income tax rates decrease after property is held more than one year, usually decline at retirement, and are zero at death. ${ }^{1}$ Little is known about the impact of these individual tax nuances on the capital markets because it is difficult to observe shareholders' tax incentives. This paper partially overcomes these measurement problems by examining a 1998 reduction in the capital gains holding period that immediately qualified some individual shareholders for the most favorable long-term capital gains tax rate. The purpose of the paper is to determine the extent to which this change in individual tax incentives affected firm-specific trading volume and share prices.

All taxable shareholders generally recognize capital gain (loss) to the extent noninventory property sells for more (less) than an investor's tax basis. However, individuals face different capital gains tax rates depending on how long they have held the property. Before the 1998 legislation, capital gains on property held for more than 18 months faced a maximum federal tax rate of 20 percent and property held for one year or less faced a maximum rate of 39.6 percent. Property held for the mid-term period (12-18 months) faced a maximum rate of 28 percent. The Internal Revenue Service Restructuring and Reform Act of 1998 (1998 Act) eliminated the mid-term period and rate retroactive to January 1, 1998, enabling investors who

\footnotetext{
${ }^{1}$ Deferral is not without costs. For example, the Wall Street Journal (July 10, 2000, A1) recently detailed the fateful sell/hold decision of a shareholder in a highly appreciated, Internet IPO. “. . . Mr. Seiff realized that if he sold the bulk of his shares before April 13 - a year and a day after he'd first exercised his options - he would have to pay the far higher tax rates for short-term capital gains. That would mean an additional $\$ 100,000$ in taxes. Mr. Seiff would still be ahead so long as Scient's shares didn't fall far below $\$ 100$ in the next two weeks. 'I was gambling,' he says, 'Wouldn't you wait two weeks for $\$ 100,000$ ?' " Unfortunately, as this investor waited for the favorable long-term capital gains tax rates applied to shares held for more than one year, his stock tumbled 77 percent to $\$ 30.25$.
} 
had held appreciated property for more than one year to receive the most favorable maximum long-term capital gains tax rate of 20 percent.

Elimination of the 18-month holding period was first disclosed publicly when the conference committee, which had been meeting in closed session, released its bill on June 24, 1998. ${ }^{2}$ Neither the House bill nor the Senate bill refers to capital gains taxes or holding periods. Both bills are motivated by perceived abuses in the Internal Revenue Service. Although conference committees occasionally insert new provisions in a bill, the empirical tests in this paper assume investors did not anticipate conferees would repeal the 18-month holding period. ${ }^{3}$ If the markets were surprised, release of the conference committee report on June 24, 1998 should have conveyed information about capital gains tax policy to investors. This paper applies conventional capital markets event study methodology to evaluate the equity markets response to the committee's repeal of the 18-month holding period.

We predict that release of the conference committee's bill triggered a surge in trading volume on June 24, 1998 as investors who had held stock for more than the 12 months period, but not more than 18 months, sold their appreciated shares. If the short-term price pressure was substantial, then share prices in appreciated firms held disproportionately by these 12-18 month investors may have decreased. ${ }^{4}$ Any impact on volume and prices should be increasing with the

\footnotetext{
${ }^{2}$ The House of Representatives and the Senate typically pass similar, but not identical, tax bills. A conference committee, headed by each houses' tax-writers, is formed to resolve differences and produce a final bill acceptable to both houses. Typically bills constructed by tax conference committees subsequently pass both houses without amendment and go to the President. Since President Clinton had indicated he would sign the 1998 Act, investors likely anticipated the bill produced by the conference committee would become law, which it did.

${ }^{3}$ Empirical results detailed below are consistent with slight leakage of information to the markets during the conference committee's closed negotiation sessions.

${ }^{4}$ To the extent a reduction in the capital gains holding period implies a reduction in future capital gains taxes, we would expect all equity to respond favorably to repeal of the 18-months holding period, similar to the market response documented in Lang and Shackelford (2000). However, this effect is not the subject of this analysis. Rather this paper addresses the cross-firm differential price effect arising from the impact of repeal on current stockholders who wish to sell their shares. That is, incentives to change trading behavior varied with the past price performance of the stock.
} 
appreciation of shares owned by individuals (the only investors affected by the policy change) who have held the stock for 12-18 months.

To enhance the power of the tests, the empirical analysis focuses on initial public offerings (IPOs) completed 12-18 months before release of the conference committee report. Although potentially limiting the generality of the results, IPOs enable observation of the holding period and share price movements experienced by their initial public shareholders. Consistent with our predictions, we find that, compared with other days and other IPOs, trading volume increased and stock returns decreased in share price appreciation on June 24, 1998 for firms whose original public shareholders had held their stock slightly more than a year.

Regression coefficient estimates imply that price declines were non-trivial, shifting at least 28 percent of the benefits of repeal from sellers to buyers through lower prices, but limited to the day that the committee released its report. Prices rebounded the following trading day. Trading volume was abnormally heavy for the week centered on the release of the committee report.

We interpret these findings in the following manner: At least some initial public shareholders wanted to sell their appreciated stock but were deferring their sales until the applicable capital gains tax rate dropped from 28 percent to 20 percent. When favorable capital gains tax treatment was suddenly possible through repeal of the 18-month holding period, some individuals sold shares that qualified for the lower rate under the immediately applicable 12month holding period. On the disclosure date, sales were sufficient in companies that had recently completed the 12 -month holding period that share prices tumbled. However, because temporary price pressure caused the price decline, prices rebounded the following day. 
To our knowledge, this is the first study linking trading volume and security prices to a change in capital gains holding periods. It joins several recent studies that show the tax treatment accorded capital gains affects share prices and trading volume (e.g., Landsman and Shackelford, 1995; Reese, 1998; Guenther and Willenborg, 1999; Blouin, Raedy and Shackelford, 2000; Collins and Kemsley, 2000; Lang and Shackelford, 2000; and Poterba and Weisbrenner, 2000).

The paper develops as follows: The next section develops testable hypotheses. Section 3 briefly reviews the relevant provisions in the legislative history of the 1998 Act. Section 4 sketches the research design. Section 5 presents the empirical findings. Closing remarks follow.

\section{Hypothesis Development}

As discussed above, the impact of the 1998 change in the holding period on trading volume and equity prices depends on (i) the stock's past price movement and (ii) the extent to which the firm's shareholders are individual investors affected by the holding period change. This leads to the paper's primary hypotheses, stated in alternative form:

$\mathrm{H}_{1}$ : Trading volume increases in the potential capital gains subject to lower tax rates when the holding period changes.

$\mathrm{H}_{2}$ : Share prices decrease in the potential capital gains subject to lower tax rates when the holding period changes.

The hypotheses should apply to liquidations of both appreciated and depreciated property. To the extent property has appreciated, capital gains are greater. Relaxing the lock-in effect created by the capital gains holding period is expected to boost trading and to diminish prices proportional to the appreciation. To the extent property has depreciated, capital gains are 
less (i.e., capital losses). Because the tax benefits of capital losses are reduced, a seller's strike is expected, proportional to the amount of lost tax savings.

Throughout the paper we assume that the effects on appreciated and depreciated securities are opposite and symmetric, and our tests are so constructed. However, our empirical tests (detailed below) only detect a response by appreciated firms. For this reason and brevity sakes, hereafter we discuss only the incentives facing holders of appreciated property.

Despite the parallel construction of the volume and price hypotheses, it is possible to reject one hypothesis and not the other. A change in trading volume is not needed for a change in share prices nor is a change in share prices needed for a change in trading volume. For example, demand from investors unaffected by the legislation (e.g., qualified plans or tax-exempt organizations) could equal the shares from selling individual investors. If so, volume could increase but prices remain constant. On the other hand, potential investors in appreciated firms held by individuals affected by the legislation could have recognized the potential sell-off and lowered their bids accordingly, capturing the tax savings. This could result in prices falling without a discernible increase in trading.

The hypotheses assume several necessary conditions hold. The shareholder must be a compliant individual who intends to sell in a taxable transaction and whose expectations are altered by the legislation. His investment horizon must approximate the relevant holding period, i.e., 12-18 months before the 1998 change. If his investment horizon is shorter or longer, the change should not affect behavior.

In addition, the legislation must have altered the individual's marginal tax rate. Before the 1998 change, the determination of the applicable marginal tax rate for a disposed property was a complex calculation that involved netting short-term, mid-term, and long-term gains and 
losses. As noted above, a maximum federal capital gains tax rate of 28 percent applied to gains of appreciated property held more than one year, but less than 18 months (mid-term gains). A maximum federal capital gains tax rate of 20 percent applied to gains on property held for a longer period (long-term gains). A maximum federal capital gains tax rate of 39.6 percent applied to gains on property held for a shorter period (short-term gains).

Of primary relevance to this study are the incentives before repeal to defer sales until the most favorable long-term capital gains tax rate of 20 percent applied. Once an appreciated property reaches the mid-term stage (i.e., held for more than a year), postponing sale until 18 months lapsed lowers an individual investor's tax liability if and only if the following conditions hold: One, during the taxable year, total mid-term capital gains realized exceed total mid-term capital losses realized. Two, during the taxable year, total mid-term and short-term capital gains realized exceed total mid-term and short-term capital losses realized. Three, long-term capital losses realized do not exceed total long-term capital gains realized. Intuitively, if these conditions are not met, mid-term losses, short-term losses or long-term losses fully offset midterm gains, leaving no gains taxed at the 28 percent rate.

Consequently, unless all these conditions hold (and obviously they do not hold for many individual investors), investors were indifferent from a tax perspective between selling immediately or waiting until the 18-month holding period was met because the marginal tax rate would be unaffected. Thus, eliminating the mid-term holding period and its 28 percent capital gains tax rate was only relevant for individual investors meeting each of these necessary conditions. The tests throughout this paper assume individual investors met the conditions.

Even if the change in the holding period affects an individual investor's marginal tax rate and thus his trading behavior, an additional condition must hold for the change to affect a firm's 
share price. Specifically, inelasticities in the supply of capital (i.e., transaction costs) must prevent immediate readjustment throughout the economy following a change in the holding period (Shackelford, 2000). Lacking inelasticities, volume could increase as individuals trade with non-individual investors without share prices changing. To the extent this assumption is not true, we should fail to detect security price responses to the 1998 reduction in the capital gains holding period.

If all the necessary conditions hold, we expect sales of appreciated shares increased following a reduction in the holding period, expanding equity and diminishing share prices temporarily. Share prices should have rebounded as investors were attracted to firms whose share prices have been depressed solely by investor-level tax incentives. The speed and completeness of the price rebound is an empirical question that we address below.

\section{Development of the 1998 Act}

Before testing the hypotheses, a brief review of the legislative history of the 1998 Act is warranted to appreciate the empirical design. On August 5, 1997, President Clinton signed the Taxpayer Relief Act of 1997. Among other changes, it lowered the maximum statutory capital gains tax rate for individuals from 28 percent to 20 percent, effective May 7, 1997, and then restricted the 20 percent rate to property that had been held for more than 18 months, effective July 29, 1997. Consequently, from May 7, 1997 to July 28, 1997, investments held for more than 12 months, but not more than 18 months, faced the 20 percent tax rate. After July 28, 1997, investments held for more than 12 months, but not more than 18 months, faced the less favorable 28 percent tax rate. 
Although various calls for repeal of the 18-month holding period arose following passage of the 1997 legislation, further tax legislation in 1997 was limited to Internal Revenue Service reform. On November 5, 1997, the House of Representatives passed the IRS Restructuring and Reform Act of 1997 by 426 to 4 . Motivated by purported IRS abuses, the bill restructured the IRS and corrected a few drafting errors in the 1997 tax act. No provision addressing any facet of capital gains tax policy was included in the bill. On May 7, 1998, the Senate unanimously passed its version of the bill, the IRS Restructuring and Reform Act of 1998. It too included IRS restructuring provisions and technical corrections to the 1997 bill, but again no capital gains tax provisions.

By mid-May conferees had been named to resolve the differences between the House and Senate bills. Asked whether the conference bill would adopt any educational tax incentives from the pending Education Savings and School Excellence Act of 1998, Senate Majority Leader Trent Lott said that he would "not play games" with the bill in conference. We find no record of his being asked or commenting on the possibility of capital gains tax changes in the conference report. Senator Majority Leader Lott and House Majority Leader Richard Armey announced that they expected a conference bill by the Memorial Day weekend (May 23-25).

Meanwhile, acting seemingly independent of the tax bill deliberations, the House Budget Committee on June 5, 1998, issued its budget resolution for the fiscal year beginning October 1, 1998. The resolution assumed elimination of the 18-month holding period, i.e., the maximum statutory rate would be 20 percent for property held more than one year.

The tax conference committee finally convened on June 10, 1998. As usual, all meetings, except its formal opening and closing sessions, were closed to the press. On June 15, 1998, Senator Lott lamented that the tax bill did not eliminate the 18-month holding period for long- 
term capital gains. The next day House Speaker Newt Gingrich predicted that in September the tax committees would construct a bill eliminating the 18 -month holding period. ${ }^{5}$

After trading had closed on June 23, 1998, the Associated Press reported that the conference committee had decided to eliminate the 18 -month holding period, retroactive to January 1 . The following day, June 24, 1998, the bill became public when the committee delivered the conference report to both chambers. The conference bill included a repeal of the 18-month holding period. ${ }^{6}$ Unlike most provisions, the conference report provided no explanation for the holding period change.

Democratic leaders expressed "outrage" at the "eleventh-hour" holding period change in the conference report. ${ }^{7}$ However, because the conference report represented the position of the leaders of both houses and the tax-writing committees, the market likely anticipated the conference report would become law. The Republican-controlled Congress certainly would not reject overwhelmingly popular IRS reform because its leaders added a provision in the conference report. The White House objected to the repeal, but President Clinton had already stated his support of the bill.

On June 25, 1998, the day following release of the conference committee report, the House passed the conference bill by 402 to 8. On July 8, 1998, Democratic Senator Byron

\footnotetext{
${ }^{5}$ It is possible that the equity markets inferred from Senator Lott's observation or Speaker Gingrich's prediction that the 18-months holding period would be repealed during the conference committee. However, empirical results detailed below provide no evidence that the capital markets responded to the Congressional leaders' comments. ${ }^{6}$ Title V (Additional Provisions) of the conference bill, which includes the holding period change, included two other provisions not included in either the House or Senate bill: a clarification of the deductibility of employee meals and a change the terminology to be used in future U.S. trade statutes, replacing "most-favored nation" with "normal trade relations." Neither provision was controversial nor should contaminate the analysis in this study. ${ }^{7}$ House Minority Leader Richard Gephart stated, "This is for the fat cat speculators on Wall Street. There was no debate, no public discussion of this. It was not in the original legislation. So it was an eleventh-hour, here it is, like it or not, take it or leave it, do-you-want-the-IRS-reform-bill kind of procedure. It is a typical jamming it at the end, which is really unfair." Senator Byron Dorgan added, "This special treat Republican legislators served up to their high income constituents was done in legislative darkness with no debate. In this case the capital gains provision was not in the House bill and not in the Senate bill. Yet, it was stuck in at the last minute in a conference committee. It's an outrage."
} 
Dorgan attempted to delay Senate voting on the bill, employing a procedural protest to the holding period reduction. His measure failed by a vote of 72 to 22 and the bill passed by 96 to 2 . President Clinton signed the bill into law on July 22, 1998.

Following passage, anecdotes in the business press asserted that the holding period change affected trading. The Wall Street Journal (August 26, 1998, A1) linked the 1998 third quarter stock market decline to selling pressure created by the reduction in the holding period. Marshall Front of Trees Front Associates observed "a much greater willingness" to sell among clients whose investments qualified for long-term capital gains under a 12-month holding period, but not under an 18-month period. Terry Banet, a vice president and portfolio manager at J.P. Morgan, cited the reduction in the holding period as "accelerat[ing] the sale of many of the positions" in stocks that qualified for long-term capital gains under the reduced holding period. The generalizability of these anecdotes is explored in the following empirical tests.

\section{Research Design}

\subsection{Regression equation}

The immediate beneficiaries of the 1998 repeal of the 18-month long-term capital gains holding period were investors who on June 24, 1998 owned appreciated stock that had been held for more than 12 months, but not more than 18 months. If they sold on the release of the conference committee report, then trading volume and equity returns should vary with appreciation on June 24, 1998. Specifically, volume should be increasing and returns decreasing 
in the extent to which equity of the firm has been held from 12 and 18 months and appreciated during that period. ${ }^{8}$

We estimate the cross-sectional variation in trading volume on June 24,1998 using the following regression:

$$
\begin{aligned}
& \boldsymbol{A} \boldsymbol{V}_{i t}=\beta_{0}+\beta_{1} \mathrm{H1218}_{i t}+\beta_{2} \boldsymbol{D} \boldsymbol{A} \boldsymbol{Y}_{t}+\beta_{3} \Delta \boldsymbol{P A S T _ { i t }}+\beta_{4} \mathrm{H}_{1218_{i t}} * \boldsymbol{D A} \boldsymbol{Y}_{t} \\
& +\beta_{5} \mathrm{H1218}_{i t}^{*} \Delta \boldsymbol{P A S T _ { i t }}+\beta_{6} \mathrm{DA} \boldsymbol{Y}_{t}^{*} \Delta \boldsymbol{P A S T _ { i t }}+\beta_{7} \mathrm{H1218}_{i t}^{*} \mathrm{DA} \boldsymbol{Y}_{t}^{*} \Delta \boldsymbol{P A S T _ { i t }}+\varepsilon_{i t}
\end{aligned}
$$

where:

$A V_{i t} \quad=$ firm i's volume on trading day $\mathrm{t}$ less the median volume for the 100 days preceding trading day $t$, where volume is trading volume divided by shares outstanding;

$H 1218_{i t}=$ categorical variable equaling one if firm i's IPO occurred no more than 18 months, but greater than 12 months, before trading day $t$ and zero otherwise;

$D A Y_{,} \quad=$ categorical variable equaling one if trading day $\mathrm{t}$ is June 24, 1998 and zero otherwise;

$\triangle P A S T_{i t} \quad=$ difference between firm i's stock price at trading day $\mathrm{t}$, adjusted for stock splits and stock dividends, and its offer price, divided by its offer price.

The key coefficient is $\beta_{7}$. A positive coefficient will be interpreted as evidence that trading increased in a firm's appreciation $(\triangle P A S T)$ on the day the committee report was released, June 24, 1998 ( $D A Y$ equals one), for firms whose IPO occurred between 12 and 18 months before the release of the conference committee report. (H1218 equals one for June 24, 1998 observations if the IPO was listed after December 23, 1996 but before June 24, 1997.) The other regressors ensure that $\beta_{7}$ is conditional on the separate effects of each interacted term ( $H 1218, D A Y, \triangle P A S T$ ) and each possible combination of the terms. The signs of the other coefficients are irrelevant to this investigation, and no predictions are advanced.

\footnotetext{
${ }^{8}$ Recall that opposite and symmetric incentives are predicted for depreciated securities. That is, volume should be decreasing and returns increasing in the extent to which equity of the firm has been held from 12 and 18 months and depreciated during that period.
} 
To evaluate stock returns on June 24,1998 , we add a regressor ( $M A R K E T$ ) to equation (1), permitting joint estimation of the covariability between the firm's return and the market's retum:

$$
\begin{aligned}
& \operatorname{RETURN}_{i t}=\beta_{0}+\beta_{1} H 1218_{i t}+\beta_{2} D A Y_{t}+\beta_{3} \Delta P A S T_{i t}+\beta_{4} H 1218_{i t} * D A Y_{t} \\
& +\beta_{5} H 1218_{i t}^{*} \Delta P A S T_{i t}+\beta_{6} D A Y_{t}^{*} \Delta P A S T_{i t}+\beta_{7} H 1218_{i t}^{*} D A Y_{t}^{*} \triangle P A S T_{i t} \\
& +\sum_{i=1}^{i=n} \gamma_{i} M A R K E T_{i t}+\varepsilon_{i t}
\end{aligned}
$$

where:

$R E T U R N_{i t}=$ firm i's stock return on trading day t;

$M A R K E T_{i t}=$ value-weighted market return if firm $\mathrm{i}$ and trading day $\mathrm{t}$ and zero otherwise.

A negative coefficient on $\beta_{7}$ will be interpreted as evidence that returns decreased in a firm's appreciation on the day the committee report was released, June 24,1998 , for firms whose IPO occurred between 12 and 18 months before the release of the conference committee report.

Consistent with Blouin, Raedy and Shackelford (2000), a positive coefficient on $\triangle P A S T$ is expected in equation (2), consistent with price momentum (Jegadeesh and Titman, 1993; Bernard, Thomas and Wahlen, 1997; and Raedy, 2000; among others). It is also consistent with $\triangle P A S T$ in its role as a separate regressor capturing tax costs (benefits) associated with selling appreciated (depreciated) shares that affect all taxable investors. This contrasts with the subject of this analysis - a change in the capital gains holding period-which only affects a subset of taxable individual investors, specifically individuals holding stock from 12-18 months. The signs of the other coefficients in the price regression are irrelevant to this investigation. 


\subsection{Sample}

The initial sample includes all IPOs on Securities Data Corporation's Platinum file and traded on the NYSE, AMEX, or Nasdaq. ${ }^{9}$ To compare trades on June 24, 1998 with trades around the release date, the regressions are conducted using information from trading days, beginning three months before the release of the committee report (March 24, 1998) and ending three months after the release of the committee report (September 24, 1998). We further narrow the sample to firms whose initial public shareholders were immediately affected by the holding period change (firms listed more than 12, but not more than 18, months before the committee's report) and to two control groups of similar duration (IPOs listed more than six, but not more than 12 , months, and IPOs listed more than 18, but not more than 24 , months, before the bill's release). The limitations create a final sample of 1,295 IPOs listed from March 24, 1996 (two years before the investigation period begins) to March 23, 1998 (one day more than six months before the investigation period ends).

The March dates ensure that for each observation in the study, the firm's initial public shareholders hold shares for more than six, but not more than 24 , months. The sample begins with March 24, 1996 because an IPO listed on that day would be exactly two years old on the first trading day in the study, March 24, 1998. A March 24, 1996 IPO would not qualify as an observation on any other trading day, i.e., on March 25, 1998 it would be more than two years old, thus disqualifying it from this analysis. IPOs completed before March 24, 1996 would be too old (more than two years) to meet the sample requirements on any trading day.

The sample ends with March 23, 1998 because an IPO listed on that day would qualify as being more than six-month old on the final trading day in the study, September 24, 1998. (It

\footnotetext{
${ }^{9}$ The sample is drawn from a wide range of industries without substantial clustering in any two-digit SIC sector, except SIC 73 (business services), which includes one-fifth of both treatment and control firms.
} 
would not qualify on any other trading days, e.g., on September 23, 1998, it would be only six months old). IPOs completed after March 23, 1998 would be too young (less than or equal to six months) to meet the sample requirements on any trading day.

Because the investigation period covers six months (March 24, 1998 through September 24, 1998), no firm has all of its trading days qualify as greater than one year, but not greater than 18 months. For example, if an IPO listed on March 23, 1997, it would be a 12-18 month observation on March 24, 1998 (the earliest trading day included in the regression). Any later listing (e.g., March 24, 1997) would not be greater than 12 months on March 24, 1998. However, the March 23, 1997 IPO firm would be greater than 18 months by September 24, 1998 (the last trading day in the study), excluding it from the 12-18 group on that day. Thus, the firm would be a 12-18 month observation on March 24, 1998, but not a 12-18 month observation on September 24, 1998. During all dates between these extreme days, the March 23, 1997 IPO firm would be included in the 12-18 group and its June 24, 1998 observation would be included in the treatment group.

\subsection{Treatment and control groups}

The "treatment" group of firm-trading days is limited to the 230 observations on June 24 , 1998 ( $D A Y$ equals one) for IPOs listed more than 12 months, but not more than 18 months, before the release date, i.e., after December 23, 1996 but before June 24, 1997 ( H1218 equals

one). Trading volume and returns for the treatment observations are compared with volume and returns for the other 120,831 firm-trading days during the period comprising: (a) 120,103 observations on days, other than June 24, 1998 ( $D A Y$ equals zero) - 34,357 involving IPOs listed 12-18 months before the trading day ( $H 1218$ equals one) and 85,746 involving IPOs of 
shorter or longer duration ( $H 1218$ equals zero), and (b) 728 observations on June 24, 1998 ( DAY equals one) for IPOs listed 6-12 months and 18-24 months before the conference committee released its report ( $H 1218$ equals zero). The group of 34,357 control observations enables comparisons between affected and unaffected IPOs of similar duration but on different days. The group of 85,746 control observations enables comparisons between the affected 12-18 month IPOs on the release date and older and younger IPOs on surrounding days. The group of 728 control observations enables comparisons of the affected IPOs on the release date with IPOs of different duration on the same day.

The dichotomization between treatment and control groups imperfectly identifies investors who have held between 12 and 18 months, biasing the regression coefficient of interest toward zero. For example, some investors in the 728 control firms may have benefited from repeal immediately. The June 24, 1998 trading day for an IPO listed in September 1997 is included in the 728 group because the firm had been public less than a year. However, an individual who bought the stock in April 1997 (before it went public) could have benefited on June 24, 1998 from repeal and sold his shares accordingly on that day. Similarly, the June 24, 1998 trading day for an IPO listed in September 1996 is included in the 728 group because the firm had been public for more than 18 months. However, an individual who bought the stock on the secondary market in April 1997 (after it went public) may have sold on June 24, 1998 in response to the same incentives under investigation in this study. In short, our imperfect identification of shareholders motivated by repeal (i.e., reliance on the initial public shareholders' holding period) biases against rejecting the null hypothesis that trading was unaffected by repeal. 


\subsection{Descriptive statistics}

Table 1 provides descriptive statistics for the regression variables for all firm-trading days for both treatment and control groups. Mean abnormal volume $\left(A V_{i t}\right)$ is significantly positive, but the median value is negative (though nearly zero), indicating skewness in the distribution. ${ }^{10}$ The mean daily return $\left(R E T U R N_{i t}\right)$ is significantly negative; however, the median RETURN is zero. Twenty-nine percent of all observations involve an IPO listed more than 12 months, but not more than 18 months, before the trading day (i.e., H1218 equals one). As detailed above, less than 1 percent of the trading days are from June 24, 1998, when $D A Y$ equals one. The mean (median) increase in share prices since the IPO listing ( $\triangle P A S T)$ is $26(3)$ percent.

\section{Regression Results}

\subsection{Trading volume tests}

\subsubsection{Primary findings}

Table 2 presents summary statistics for ordinary least square estimates of equation (1) where the dependent variable is abnormal daily trading volume. The purpose of this test is to assess whether firms whose initial public shareholders were affected by the change in holding period exhibited unusual trading on June 24, 1998, compared with their trading on other days and the trading of similar IPOs on that day and surrounding days.

Panel A's first column shows results using all firms in the sample. The regression coefficient estimates indicate that, on average, trading volume was abnormally heavy during the

\footnotetext{
${ }^{10}$ To control for extreme values, we winsorize $A V$ and $\triangle P A S T$ at their outer one-percent tails. No other variables are winsorized because their values are not as extreme.
} 
investigation period (intercept is positive) and even heavier on June 24, 1998 (coefficient on $D A Y$ is positive) and for IPOs listed $12-18$ months earlier (coefficient on $H 1218$ is positive). ${ }^{11}$ However, 12-18 month IPOs were less active on June 24, 1998 than on other days (coefficient on the product of $H 1218$ and $D A Y$ is negative). Furthermore, abnormal volume is increasing in firms' appreciation since the IPO (coefficient on $\triangle P A S T$ is positive) and particularly so for IPOs completed 12-18 months earlier (coefficient on the product of H1218 and $\triangle P A S T$ is positive). Most importantly for this study, the coefficient on the interaction of $H 1218, D A Y$, and $\triangle P A S T$ is positive and significant at conventional levels, as predicted. In other words, abnormal volume is increasing in firms' appreciation since their IPO and particularly so on June 24, 1998 for IPOs completed 12-18 months earlier.

Further analysis shows that the result is limited to shareholders facing capital gains. When equation (1) is separately estimated for the 59,335 firm-days with depreciated shares (i.e., $\triangle P A S T$ is negative), the interaction coefficient is negative (-0.65), though not significantly different from zero. When equation (1) is separately estimated for the 61,726 firm-days with appreciated shares (i.e., $\triangle P A S T$ is positive), the interaction coefficient is positive (0.49), significantly greater than zero, and significantly greater than the coefficient on the depreciated subsample. This finding indicates that although repeal reduced the tax savings associated with selling shares of depreciated securities, any seller's strike that materialized following repeal was not substantial enough to detect using these tests of trading volume. One explanation for the difference between appreciated and depreciated firms is that shareholders in appreciated firms had never been able to sell at the most favorable rate and thus responded immediately to repeal

\footnotetext{
${ }^{11}$ The null hypothesis of correct model specification under White's (1980) test is rejected at conventional levels. The reported standard errors are computed using White's (1980) consistent covariance matrix estimation to correct for an unspecified form of heteroskedasticity. However, the results are qualitatively unaltered when the ordinary least squares standard errors are used.
} 
while shareholders in depreciated firms had always had the option to sell and receive favorable tax treatment. Perhaps those who valued the tax benefits of selling depreciated stock had already sold their shares. Limits on the deductibility of losses may also explain the failure to detect a change in trading volume for depreciated securities. The deduction for capital losses (net of capital gains) is limited to $\$ 3,000$ and offsets ordinary income (i.e., is unaffected by capital gains tax rates).

\subsubsection{Additional tests}

This section presents results from alternative specifications designed to assess further the cross-sectional variation in June 24, 1998 trading volume. The first test is motivated by the differential benefits of repeal depending on when the IPO listed. In particular, the repeal benefits firms that listed just over one year before the release date more than firms that had nearly reached the 18-month qualification period. For example, suppose the IPO occurred on December 24, 1996. On June 25, 1998, investors would have met the 18-month holding period and could have sold their shares at the favorable long-term capital gains tax rate of 20 percent. Thus, the repeal accelerated trading by no more than one day. Alternatively, if the IPO listed on June 23, 1997, repeal accelerated tax-favored selling by a full six months (from December 24, 1998 to June 24, 1998). In addition, the older the IPO, the less likely the original public shareholders still hold shares in the company, reducing the relevance of the holding period reduction. Consequently, we expect that the more recent IPOs in the 12-18 month group exhibited more abnormal trading volume than the earlier IPOs in the treatment group.

To test this prediction, we limit the treatment group to firms listing more than 12 months, but not more than 14 months, before the release date (12-14 IPOs), i.e., IPOs completed from 
April 24, 1997 to June 23, 1997. The treatment group now comprises 91 observations from June 24, 1998 for firms whose initial public shareholders should have benefited more from repeal than shareholders of earlier IPOs. IPOs completed more than 14 months, but less than 18 months, before the repeal are excluded from this additional test.

Consistent with our predictions, the second column in Table 2, Panel A shows that the coefficient on the three-way interaction for the 12-14 IPOs is nearly twice the coefficient for the whole sample (0.57 vs. 0.32$)$. Furthermore, when we repeat this procedure for two groups of older IPOs (i.e., IPOs completed more than 14, but not more than 16, months and IPOs completed more than 16 , but not more than 18 , months), neither coefficient is significantly different from zero. We infer from these results that the increase in trading volume was limited to those IPOs that benefited most from the repeal, i.e., those that had most recently reached the one-year holding period.

The second extension introduces a measure intended to capture the extent to which taxable individual investors influence trading in the firm's equity. IND is the percentage of a firm owned by non-institutional investors as reported by Spectrum. Table 1 shows that mean (median) non-institutional ownership is $76(80)$ percent, but the percentage ranges from less than 2 percent to the entire company.

$I N D$ is included as a separate regressor and interacted with each of the original regressors. We predict that the regression coefficient estimate on the four-way interaction (the product of $H 1218, D A Y, \triangle P A S T$, and $I N D$ ) will be positive, consistent with trading volume increasing in the extent of individual ownership for appreciated 12-18 month firms on June 24, 1998. 
The first column of Table 2, Panel B only reports the coefficient estimates and standard errors for $I N D$, when it is included separately in the regression, and for the four-way interaction term when all firms are examined. The coefficient on IND is significantly less than zero, indicating that trading is decreasing in individual ownership. However, the four-way interaction coefficient is not significantly different from zero, providing no evidence that the tax-motivated trading on June 24, 1998 varied with the percentage of individual ownership. The interaction coefficients also are insignificantly different from zero for each of three sub-samples. ${ }^{12}$

The final extension interacts $H 1218, D A Y$, and $\triangle P A S T$ with a measure designed to estimate the number of shares affected by the holding period change. IPO $\%$ is the percentage of the firm's shares sold in the IPO. Table 1 shows that firms sold 36 percent of their stock at the IPO, on average, but the amount ranges from 0.4 percent to the entire company. We predict that the shares sold in response to the repeal are increasing in the number of shares sold at the IPO, ceteris paribus. That is, the number of shares affected by the committee's repeal should be increasing in the number of shares whose holding period began at the IPO.

As with IND, IPO\% is included as a separate regressor and interacted with each of the original regressors. Again, the variable of primary interest is the four-way interaction. We predict that the sign of the coefficient on the four-way interaction involving $I P O \%$ will be positive.

The first column of Table 2, Panel $\mathrm{C}$ reports only the coefficient estimates and standard errors for $I P O \%$ and the four-way interaction term. Contrary to expectations, the interaction

\footnotetext{
${ }^{12}$ Blouin, Raedy and Shackelford (2000) discuss the shortcomings of using Spectrum data in this context. Briefly, the ideal measure would distinguish between investments that affect the capital gains and losses reported on individuals' tax returns (e.g., personal accounts, street-name, trusts, mutual funds, partnerships, S corporations, limited liability corporations, and other entities that pass-through taxable gains and losses from investments) and those that do not (e.g., closely-held C corporations, individual retirement accounts, 401(k) retirement accounts, and other defined contribution plans). Unfortunately, to our knowledge, no public data provide such detail.
} 
coefficient is negative, though not significant. The coefficient, however, is significantly negative for the 12-14 month IPOs. We conclude that this additional test provides no evidence that taxmotivated trading on June 24, 1998 varied with the percentage of the company sold at the IPO. ${ }^{13}$

\subsection{Equity returns tests}

\subsubsection{Primary findings}

This section reports results from tests designed to assess whether the increase in trading volume on June 24, 1998 impacted share prices. Table 3 presents summary statistics for ordinary least square estimates of equation (2), where the dependent variable is firm-level stock returns. The regression coefficient estimate on $H 1218 * D A Y$ in the first column of Table 3, Panel A shows that on June 24, 1998, market-model adjusted returns for 12-18 month firms were up 1 percent. The regression results also indicate that stock returns are increasing in past price performance, as expected and consistent with both the lock-in effect that impacts all taxable investors (i.e., the incentive to defer selling appreciated property) and price momentum.

Of primary importance to this study, the coefficient on the interaction of $H 1218, D A Y$, and $\triangle P A S T$ is significantly negative, as predicted. In other words, on June 24, 1998 for IPOs completed 12-18 months earlier, returns were declining in firms' appreciation since their IPO. This finding is consistent with downward price pressure from the selling at the release date by shareholders in appreciated firms who had met the 12-month capital gains holding period, but not the 18-month holding period.

The Pearson correlation coefficient between abnormal volume $(A V)$ and the absolute

\footnotetext{
${ }^{13}$ One possible reason for the failure to detect that trading varied with the percentage of the company sold at the IPO is that $I P O \%$ imperfectly captures the relevance of repeal to a firm's shareholders. In particular, $I P O \%$ ignores any selling by original public shareholders before the committee released its bill.
} 
value of share returns ( RETURN ) is positive (0.24) and significant at the 0.001 level for the 230 treatment observations on June 24, 1998. This result indicates an association between heavy trading volume and stock price movements, consistent with repeal of the 18-month holding period triggering changes in trading behavior that affected stock prices.

Finally, to better assess whether nontax information moved the prices on June 24, 1998, we review the Wall Street Journal for news on the day of the committee's repeal and the following day for the firms that appear to fit the predictions most closely. Specifically, we evaluate the nine IPOs listed more than 12 months, but less than 13 months, before the committee's report that had June 24, 1998 abnormal price declines exceeding 1.5 percent and had appreciated more than 30 percent since their IPO. ${ }^{14}$ All, but one, had individual ownership exceeding 62 percent. Each sold more than 19 percent at its IPO. The Wall Street Journal reported nothing about any of the nine companies on either day, leading us to infer that whatever caused the dramatic price movements on June 24, 1998 for these companies was not deemed newsworthy. Therefore, we are unable to identify any nontax information that may explain the findings for these firms.

\subsubsection{Economic significance}

The economic significance of the regression coefficient estimate on the three-way interaction is non-trivial. The coefficient implies that the June 24, 1998 market-model adjusted return for a 12-18 month firm whose value had doubled since its IPO was 1.07 percent (270 percent annualized) less than the adjusted return for (a) that firm on another day, (b) an identical firm on that day whose value was unchanged since its listing, or (c) a 6-12 month or 18-24

\footnotetext{
${ }^{14}$ The nine firms are Aris, Boston Properties, Maximum, American Retirement Corporation, Star

Telecommunications, CFI Mortgage, New Era of Networks, IWL Communications, and NetSpeak.
} 
month IPO with the same appreciation on any day. ${ }^{15}$ Similarly, an interquartile increase in the interaction variable decreases the single-day, market-model adjusted return by 1.2 percent (307 percent annualized). ${ }^{16}$

The coefficient also can be used to estimate the incidence of repeal. Suppose an investor intended to sell on June 24, 1998 and pay capital gains taxes equaling 28 percent of the stock's appreciation. Thus, the repeal was an unanticipated and immediate windfall to be shared by seller and buyer.

To compute the post-repeal price that leaves the investor indifferent between selling before the price fell and paying capital gains taxes at the 28 percent rate and selling after the price fell and paying taxes at the 20 percent rate, let $P(1-\tau)+B \tau$ equal the after-tax proceeds where $P$ is the sales price, $B$ is the tax basis, and $\tau$ is the capital gains tax rate. A change in the holding period alters the applicable capital gains tax rate $(\Delta \tau)$, leaving the after-tax proceeds unchanged if the price falls by $\frac{\Delta \tau(P-B)}{1-\tau-\Delta \tau}$. Using federal tax rates at repeal, a 10 percent decline in the share's appreciation $(P-B)$ fully offsets an eight percentage point drop in the capital gains tax rate (see Guenther, 1999, and Shackelford, 2000 for similar analyses). In other words, if the stock's appreciation drops by 10 percent upon news of the repeal, the benefits of the holding period reduction are fully shifted from the sellers of the stock to the buyers of the stock through a lower sales price.

Evaluated at the mean appreciation (0.39) for the affected firms on June 24, 1998, the upper bound for a price decline in response to the repeal of the 18 -month holding period is a 2.8

\footnotetext{
${ }^{15}$ The annualized return is computed as a conventional measure for comparison and is not an implementable trading strategy.

${ }^{16}$ For those observations with both $H 1218$ and $D A Y$ equaling one, the first quartile for $\triangle P A S T$ is -0.37 and the third quartile is 0.77 . 1.2 percent is $0.77+0.37$ times the coefficient of -1.07 .
} 
percent drop in value. ${ }^{17}$ The coefficient estimate of -1.07 implies that the mean affected firm suffered an incremental price decline of 0.4 percent $(-1.07 * 0.39)$. Thus, the regression coefficient estimate on the interaction implies that buyers extracted at least $14(0.4 / 2.8)$ percent of the tax benefits associated with the holding period change through lower sales prices. Alternatively stated, sellers retained no more than 86 percent of the possible tax benefits attributable to repeal.

\subsubsection{Specification checks}

As discussed above, the returns equation differs from the volume equation because the former includes 1,240 separate MARKET regressors to enable joint estimation of the covariability between the firm's return and the market's return. ${ }^{18}$ A downside of this specification is that the size of the model overwhelms our computational capacities for testing an unknown form of heteroskedasticity using White's (1980) approach. Thus, we are unable to assess whether the standard errors are understated using White's (1980) test, as we did with the volume regressions.

As an alternative specification check, we modified equation (2) to limit the analysis to the 958 observations on June 24, 1998 (230 are treatment firms, i.e., 12-18 month firms, and 738 are control firms, i.e., 6-12 or 18-24 month firms) and to three regressors: H1218, $\triangle P A S T$, and an interaction of the two variables. The dependent variable is firm-specific abnormal returns, where beta is estimated in the 100-day period preceding June 24, 1998. The modified equation is identical to the original one, except market-adjusted returns are not jointly estimated and controls

\footnotetext{
${ }^{17} 2.8$ percent is 10 percent of the mean $\triangle P A S T$ (0.39) divided by 1.39 (one plus the mean appreciation).

${ }^{18}$ The number of $M A R K E T$ regressors $(1,240)$ differs from the number of sample firms $(1,295)$ because a single $M A R K E T$ regressor is used for the 56 firms with less than ten trading days during the investigation period.
} 
for other trading days are unnecessary (thus $D A Y$ and its interactions are excluded from the regressors). We predict that daily returns are decreasing in the product of $H 1218$ and $\triangle P A S T$, i.e., stock returns are decreasing in appreciation for 12-18 month firms on June 24, 1998.

When we test this simpler regression using White's (1980) approach, we fail to reject the null hypothesis of correct model specification. The estimated coefficient on the interaction for the modified regression is identical $(-1.07)$ to the one found using the complete model and again significant at the 0.05 level. We infer from this finding that the original results are reliable.

However, our confidence in the specification of the returns model does not extend to all variants of the model. For example, when we use the modified equation to estimate equation (2) separately for the 59,335 firm-days with depreciated shares (i.e., $\triangle P A S T$ is negative) and for the 61,726 firm-days with appreciated shares (i.e., $\triangle P A S T$ is positive), the null hypothesis of correct model specification under White's (1980) test is rejected at conventional levels for both regressions. Using White's (1980) consistent covariance matrix estimation to correct for an unspecified form of heteroskedasticity, we find that the coefficients on the interactions of interest are neither significantly different from zero nor significantly different between the appreciated and the depreciated subsamples. We infer from these findings that: (a) some of the returns extensions may suffer from model misspecification (further suspicions are noted below) and (b) unlike the volume results, the return results are not driven solely by the appreciated firms.

\subsubsection{Additional tests}

Using equation (2), we repeat the additional tests discussed in the previous section. Consistent with expectations, we find the price response varied with the recency of the IPO and 
perhaps the percentage of the firm held by individuals and the percentage of the firm sold at the IPO.

The second column of Table 3, Panel A shows that the coefficient on the three-way interaction for the 12-14 month IPOs is almost twice the coefficient for the whole sample $(-2.09$ vs. -1.07). The coefficient implies that the June 24, 1998 market-model adjusted return for a 1214 month firm whose value had doubled since its IPO was 2.09 percent (527 percent annualized) less than the adjusted return for (a) that firm on another day, (b) an identical firm on that day whose value was unchanged since its listing, or (c) a 6-12 month or 18-24 month IPO with the same appreciation on any day. Similarly, an interquartile increase in the interaction variable decreases the single-day, market-model adjusted return by 2.2 percent ( 553 percent annualized). Using the same computation as above, this coefficient further implies that buyers extract at least 28 percent of the tax benefits associated with the holding period change through lower share prices. When the estimation is repeated for the other older IPOs (14-16 months and 16-18 months), no coefficient is significantly different from zero. As with the trading volume results, we infer from these results that the June 24, 1998 tumble in share prices was limited to those IPOs that benefited most from the repeal, i.e., those that had just reached the one-year holding period.

Table 3, Panel B reports the coefficient estimates and standard errors for IND and the four-way interaction term. We find returns are increasing in individual ownership. More importantly, as expected, the coefficient on the four-way interaction is negative and significant at the 0.05 level using a one-tailed test. Unlike the volume tests, these results provide evidence that price responses to the repeal are increasing in individual ownership. The individual effect is particularly pronounced among the IPOs that have most recently met the 12-month holding 
period. The coefficient on the interaction using the 12-14 firms is fivefold the coefficient using all firms and highly significant.

The significance, however, may arise from an understated standard error. When the simpler, modified returns model for June 24, 1998 observations only (discussed above) is estimated for the 12-14 month firms, the null hypothesis of correct model specification under White's (1980) test is rejected at conventional levels, and the interaction coefficient is not significantly different from zero using the standard error from White's (1980) consistent covariance matrix estimation. Neither the interaction coefficient on the 14-16 month group nor the interaction coefficient on the 16-18 month groups is significantly different from zero under either model.

Finally, returns may vary with the percentage of the company sold at the IPO. Table 3, Panel $\mathrm{C}$ reports the coefficient estimates and standard errors for $I P O \%$ and the four-way interaction. As predicted, the coefficient is significantly negative, consistent with share return falling with the percentage of the company sold in the IPO for appreciated 12-18 month firms on June 24, 1998. Unlike the volume tests, these results provide evidence that price responses to the repeal are stronger for firms with more initial public shareholders. Once again, the 12-14 month IPOs show the greatest responsiveness.

Standard errors, however, may again be understated for both the complete sample and the 12-14 month subsample. When the modified returns model is estimated for both groups, the null hypothesis of correct model specification under White's (1980) test is rejected both times, and the interaction coefficients are not significantly different from zero using the standard errors from White's (1980) consistent covariance matrix estimation. Neither the interaction coefficient 
on the 14-16 month group nor the interaction coefficient on the 16-18 month group is significantly different from zero using either model.

\subsection{Speed of Adjustment}

To summarize, the findings presented in Table 2 and 3 are consistent with shares being sold on the day the conference committee publicly announced its repeal of the 18-month holding period, driving down share prices. The volume and price effect is concentrated among IPOs that had recently completed the 12 -month holding period.

The final tests assess the period over which news of the repeal affected trading volume and share prices. To assess the speed and completeness of the equity market response to the legislative information, we repeated the volume and price regression analyses for the 30 trading days from June 10, 1998 (when the conferees first met) to July 22, 1998 (when President Clinton signed the 1998 Act into law). All variables remain the same, except $D A Y$ is redefined as one if the trading day $t$ is the evaluated day, otherwise zero.

\subsubsection{Trading volume results}

Table 4 reports the regression coefficients for the three-way interaction of $H 1218, D A Y$, and $\triangle P A S T$, using both volume and return data for the 30 trading days. ${ }^{19}$ When equation (1) is estimated with abnormal volume as the dependent variable, the interaction coefficients are only significant on June 22, 24, and 25. For the week centered on the Wednesday that the committee released its report, the interaction coefficients average 0.27 . For the period preceding (following) that week, the coefficients average $0.09(0.07)$. The significant June 22 volume

\footnotetext{
${ }^{19}$ Inferences are qualitatively unchanged when the analysis is conducted with 12-14 month IPOs as the treatment sample.
} 
response suggests that some investors changed their expectations about the applicable capital gains tax rate in advance of the committee's release of the bill, consistent with leakage to the market about repeal.

\subsubsection{Equity returns results}

The share price response is even more concentrated than the volume response. When equation (2) is estimated with stock returns as the dependent variable, June 24, 1998 is the only day that the interaction coefficient is significantly negative, consistent with the conference committee's release date being the only date that the supply of buyers was inadequate to handle the price pressure.

If short-term pressure accounted for the price decline on June 24, 1998, then we would expect a price rebound. In other words, if inelasticities in the supply of capital enabled share prices of appreciated firms to fall as individual shareholders liquidated their positions upon news of the repeal, then we would expect the returns of these firms to outperform the market in succeeding trading days.

We find evidence of a rebound on June 25, 1998. The interaction coefficient is positive and significant, indicating that share prices were increasing in appreciation for 12-18 month

firms on the day following the committee's release. The interaction coefficients remain positive (though not significant) for the next four trading days. Assuming a binomial distribution, the probability of five consecutive positive coefficients is 0.03 , providing further evidence of a rebound in the days following the June 24, 1998 price decline. As further indication of a rebound, the Pearson correlation coefficient is -0.30 (significant at the 0.001 level) for the market-model-adjusted abnormal returns of the treatment firms on June 24 and June 25. 


\section{Closing Remarks}

This paper exploits an unusually powerful setting to explore a choice many individual investors face regularly — the decision to sell today or postpone selling until lower rates are available in the future. Evidence presented in this paper indicates that trading volume soared and share prices fell for firms whose initial public shareholders benefited from the 1998 repeal of the 18-month capital gains holding period. The results imply that capital gains holding periods distort markets sufficiently that if investors are permitted to liquidate appreciated positions at favorable rates, enough will sell immediately to move prices. Future research is warranted to determine whether the impact of capital gains taxation on equity trading is sufficient to materially alter trading volume and share prices under more normal conditions.

By calibrating the effects of holding period changes on security trading, these findings should interest tax and valuation scholars. Documentation that investors respond to changes in capital gains holding periods adds to the burgeoning empirical (Amoako-Adu, Rashid and Stebbins, 1992; Landsman and Shackelford, 1995; Erickson, 1998; Reese, 1998; Guenther 1999; Guenther and Willenborg, 1999; Blouin, Raedy and Shackelford, 2000; Klein, 2000; Lang and Shackelford, 2000; Poterba and Weisbrenner, 2000; Sinai and Gyourko, 2000; among others) and theoretical (Klein, 1999; Shackelford and Verrecchia, 2000; Collins and Kemsley, 2000; among others) literature linking equity trading to capital gains taxes.

Besides their scholarly contribution, these findings should be useful to policymakers considering further changes in capital gains holding periods. For example, Senate Majority Leader Trent Lott and Senator Robert Torricelli recently proposed reducing the long-term capital gains holding period from 12 months to three months (Wall Street Journal, May 24, 2000, A1). The results in this paper suggest that such a change would cause trading volume and share prices 
to vary with the accrued capital gains for individuals who have held shares between three and 12 months and particularly those who have just met the three month hurdle. 


\section{References}

Amoako-Adu, B., Rashid, M., Stebbins, M., 1992. Capital gains tax and equity values: Empirical test of stock price reaction to the introduction and reduction of capital gains tax exemption. Journal of Banking and Finance 16, 275-287.

Bernard, V., Thomas, J., Wahlen J., 1997. Accounting-based stock price anomalies: Separating market inefficiencies from risk. Contemporary Accounting Research 14: 89-136.

Blouin, J., Raedy, J., Shackelford, D., 2000. Capital gains taxes and stock reactions to quarterly earnings announcements. NBER working paper W7644.

Collins, J., Kemsley D., 2000. Capital gains and dividend capitalization in firm valuation: Evidence of triple taxation. Accounting Review, forthcoming.

Erickson, M., 1998. The effect of taxes on the structure of corporate acquisitions. Journal of Accounting Research 36, 279-298.

Guenther, D., 1999. Investor reaction to anticipated 1997 capital gains tax rate reduction. University of Colorado, Boulder, CO, working paper.

Guenther, D., Willenborg M., 1999. Capital gains tax rates and the cost of capital for small business: Evidence from the IPO market. Journal of Financial Economics 53, 385-408.

Jegadeesh, N., Titman S., 1993. Returns to buying winners and selling losers: Implication of stock market efficiency. Journal of Finance 44: 135-148.

Klein, P., 1999. The capital gain lock-in effect and equilibrium returns. Journal of Public Economics 71, 355-378 .

Klein, P., 2000. The capital gain lock-in effect and long horizon return reversal. Journal of Financial Economics, forthcoming.

Landsman, W., Shackelford D., 1995. The lock-in effect of capital gains taxes: Evidence from the RJR Nabisco leveraged buyout. National Tax Journal 48, 245-59.

Lang, M., Shackelford D., 2000. Capitalization of capital gains taxes: Evidence from stock price reactions to the 1997 rate reductions. Journal of Public Economics 76: 69-85.

Poterba, J., Weisbrenner S., 2000, Capital gains tax rules, tax-loss trading, and turn-of-the-year returns. Journal of Finance, forthcoming.

Raedy, J. 2000. A reconciliation of stock market anomalies. University of North Carolina, Chapel Hill, NC, working paper. 
Reese, W., 1998. Capital gains taxation and stock market activity: Evidence from IPOs. Journal of Finance 53, 1799-1820.

Shackelford, D., 2000. Stock market reaction to capital gains tax changes: Empirical evidence from the 1997 and 1998 Tax Acts. In: Poterba, J. (Ed.), Tax Policy and the Economy, vol. 14., National Bureau of Economic Research and MIT Press, Cambridge, MA, 67-92.

Shackelford, D., Verrecchia R., 2000. Intertemporal tax discontinuities. University of North Carolina, Chapel Hill, NC, working paper.

Sinai, T., Gyourko J., 2000. The asset price incidence of capital gains taxes: Evidence from the Taxpayer Relief Act of 1997 and publicly-traded real estate firms. University of Pennsylvania, Philadelphia, PA, working paper.

White, H., 1980. A heteroscedasticity-consistent covariance matrix estimator and a direct test for heteroscedasticity. Econometrica, 817-838. 
Table 1

Descriptive statistics

Sample observations are the 121,061 trading days from March 24, 1998 through September 24, 1998 for initial public offerings from 1996, 1997, and 1998

Event date (DAY) is June 24, 1998;

Treatment group ( H1218 ) includes IPOs after December 23, 1996 and before June 24, 1997;

\begin{tabular}{|c|c|c|c|c|c|c|c|}
\hline & Mean & std dev & $1 \%$ & $25 \%$ & Median & $75 \%$ & $99 \%$ \\
\hline$A V$ & 0.23 & 1.00 & -1.22 & -0.16 & -0.01 & 0.26 & 6.36 \\
\hline RETURN & -0.20 & 6.03 & -15.91 & -2.38 & 0 & 1.67 & 17.78 \\
\hline$H 1218$ & 0.29 & & & & & & \\
\hline$D A Y$ & 0.01 & & & & & & \\
\hline$\triangle P A S T$ & 0.26 & 0.94 & -0.91 & -0.42 & 0.03 & 0.69 & 3.98 \\
\hline$I N D$ & 0.76 & 0.22 & 0.15 & 0.64 & 0.80 & 0.95 & 1.00 \\
\hline$I P O \%$ & 0.36 & 0.20 & 0.03 & 0.23 & 0.32 & 0.44 & 0.86 \\
\hline
\end{tabular}

$A V_{i t}$ is firm i's volume on day $\mathrm{t}$ less the median volume for the 100 days preceding day $\mathrm{t}$, where volume is trading volume divided by shares outstanding, times 100; RETURN $N_{i t}$ is firm i's stock return on trading day t times 100; H1218 is a categorical variable equaling one if firm i's IPO occurred after December 23, 1996 and before June 24, 1997 and zero otherwise; $D A Y_{t}$ is a categorical variable equaling one if trading day $\mathrm{t}$ is June 24,1998 and zero otherwise; $\triangle P A S T_{i t}$ is the difference between firm i's stock price at trading day $\mathrm{t}$, adjusted for stock splits and stock dividends, and its offer price, divided by its offer price; IND is the percentage of firm i's shares held by individuals; IPO\% is the percentage of firm i's shares sold in the IPO. 


\section{Table 2}

Coefficient estimates (standard errors) from ordinary least squares regressions;

Dependent variable: abnormal daily volume ( $A V)$;

Sample observations are the trading days from March 24, 1998 through September 24,

1998 for initial public offerings from 1996, 1997, and 1998

Event date (DAY) is June 24, 1998.

\begin{tabular}{|c|c|c|c|c|c|}
\hline \multicolumn{6}{|c|}{ Months before repeal that IPO was listed ${ }^{b}$} \\
\hline Panel $A$ & pred & All firms ${ }^{a}$ & $>12 \& \leq 14$ & $>14 \& \leq 16$ & $>16 \& \leq 18$ \\
\hline Intercept & & $0.18 * *$ & $0.18 * *$ & $0.18^{* *}$ & $0.18^{* *}$ \\
\hline$H 1218$ & & $0.06^{* *}$ & $0.06^{* *}$ & $0.04 * *$ & $0.07 * *$ \\
\hline$D A Y$ & & $0.10 *$ & $0.10 *$ & $0.10 *$ & $0.10 *$ \\
\hline$\triangle P A S T$ & & $0.12 * *$ & $0.12 * *$ & $0.12 * *$ & $0.12 * *$ \\
\hline$H 1218 * D A Y$ & & $-0.17 *$ & -0.15 & -0.13 & $-0.21 *$ \\
\hline$H 1218 * \triangle P A S T$ & & $0.09 * *$ & $0.05^{*}$ & $0.14 * *$ & $0.07 * *$ \\
\hline$D A Y * \Delta P A S T$ & & 0.08 & 0.08 & 0.08 & 0.08 \\
\hline$H 1218 * D A Y * \triangle P A S T$ & $(+)$ & $\begin{array}{l}0.32 * \\
(0.15)\end{array}$ & $\begin{array}{l}0.57 * \\
(0.25)\end{array}$ & $\begin{array}{c}0.03 \\
(0.18) \\
\end{array}$ & $\begin{array}{c}0.29 \\
(0.26) \\
\end{array}$ \\
\hline$\frac{\text { Panel } \boldsymbol{B}}{I N D}$ & & $-0.09 * *$ & $-0.09 * *$ & $-0.09 * *$ & $-0.09 * *$ \\
\hline $\begin{array}{l}H 1218^{*} D A Y^{*} \triangle P A S T \\
* \text { IND }\end{array}$ & $(+)$ & $\begin{array}{l}-0.63 \\
(0.77) \\
\end{array}$ & $\begin{array}{l}-1.41 \\
(1.35) \\
\end{array}$ & $\begin{array}{c}0.43 \\
(0.90) \\
\end{array}$ & $\begin{array}{l}-0.76 \\
(1.07) \\
\end{array}$ \\
\hline$\frac{\text { Panel } C}{I P O \%}$ & & $-0.05 *$ & $-0.05^{*}$ & $-0.05^{*}$ & $-0.05 *$ \\
\hline $\begin{array}{l}H 1218 * D A Y^{*} \triangle P A S T \\
* \boldsymbol{I P O} \%\end{array}$ & $(+)$ & $\begin{array}{l}-0.91 \\
(0.93)\end{array}$ & $\begin{array}{l}-2.24 * \\
(0.85)\end{array}$ & $\begin{array}{l}-0.29 \\
(0.89) \\
\end{array}$ & $\begin{array}{c}0.48 \\
(2.09) \\
\end{array}$ \\
\hline $\mathrm{N}$ & & 121,061 & 97,761 & 96,890 & 99,358 \\
\hline
\end{tabular}

** significant at 0.001 level (two-tailed test)

* significant at 0.05 level (two-tailed test)

See Table 1 for variable descriptions.

a All firms: Treatment sample ( H1218=1) is IPOs completed from December 24, 1996-June 23, 1997.

${ }^{b}>12 \& \leq 14$ months: Treatment sample $(H 1218=1)$ is IPOs completed from April 24, 1997 —June 23, 1997

Excludes IPOs completed from December 24, 1996-April 23, 1997

$>14 \& \leq 16$ months: Treatment sample $(H 1218=1)$ is IPOs completed from February 24, 1997-April 23, 1997

Excludes IPOs completed from December 24, 1996-February 23, 1997 and from April 24, 1997-June 23, 1997

$>16 \& \leq 18$ months: Treatment sample $(H 1218=1)$ is IPOs completed from December 24,1996 -February 23, 1997

Excludes IPOs completed from February 24, 1997_June 23, 1997 


\section{Table 3}

Coefficient estimates (standard errors) from ordinary least squares regressions;

Dependent variable: daily returns ( RETURN);

\section{Sample observations are the trading days from March 24, 1998 through September 24, 1998 for initial public offerings from 1996, 1997, and 1998 \\ Event date (DAY) is June 24, 1998.}

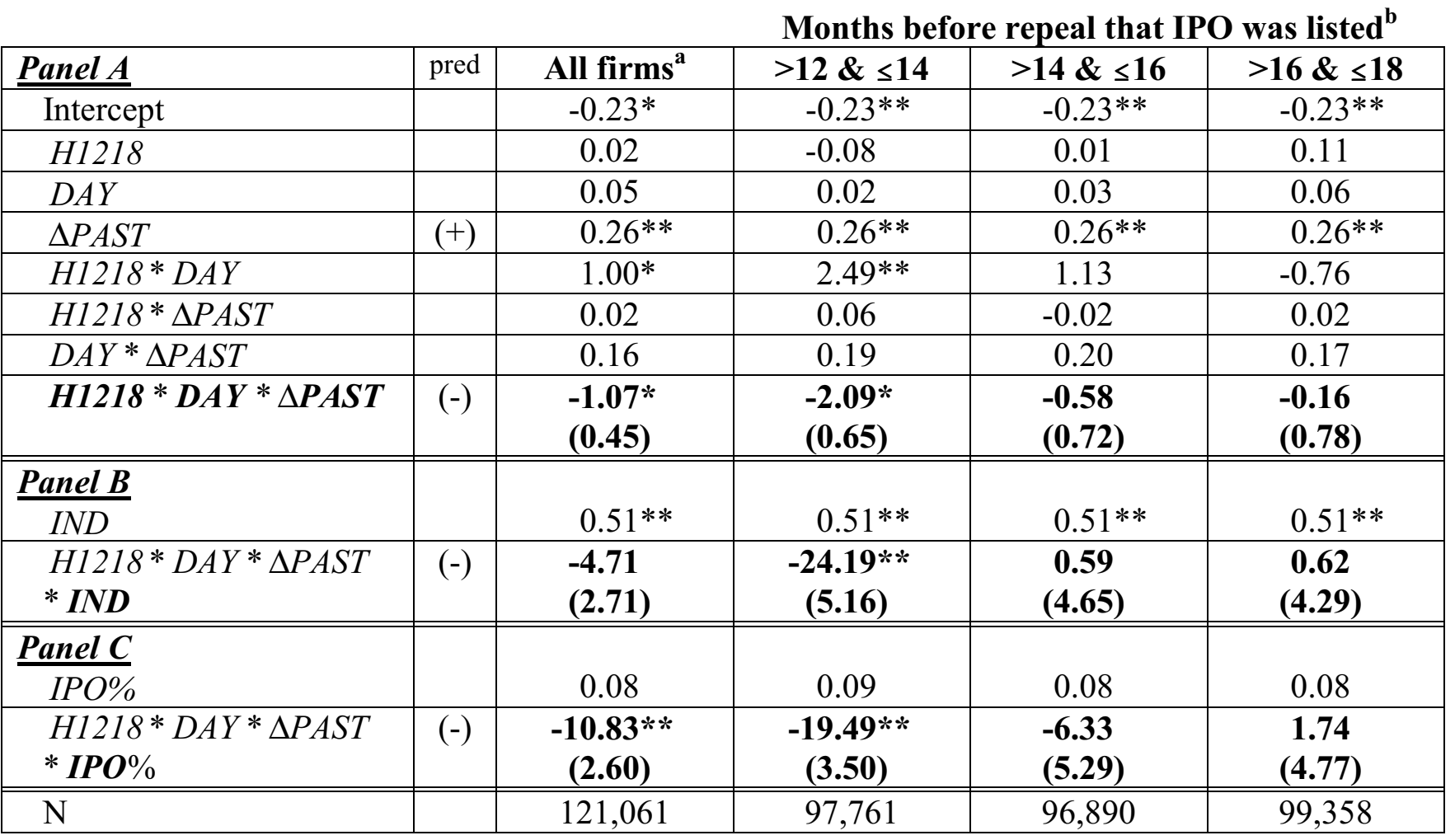

** significant at 0.001 level (two-tailed test)

* significant at 0.05 level (two-tailed test)

See Table 1 for variable descriptions.

${ }^{a}$ All firms: Treatment sample ( H1218=1) is IPOs completed from December 24, 1996-June 23, 1997.

${ }^{b}>12 \& \leq 14$ months: Treatment sample $(H 1218=1)$ is IPOs completed from April 24, 1997 —June 23, 1997 Excludes IPOs completed from December 24, 1996-April 23, 1997

$>14 \& \leq 16$ months: Treatment sample $(H 1218=1)$ is IPOs completed from February 24, 1997-April 23, 1997 Excludes IPOs completed from December 24, 1996-February 23, 1997 and from April 24, 1997-June 23, 1997

$>16 \& \leq 18$ months: Treatment sample $(H 1218=1)$ is IPOs completed from December 24,1996 -February 23, 1997

Excludes IPOs completed from February 24, 1997_June 23, 1997 
Table 4

$\beta_{7}$ coefficient estimate from ordinary least squares regressions of daily trading volume and share returns from initial public offerings in 1996, 1997, and 1998; event day (DAY) is each trading day from June 5, 1998 through July 22, 1998; treatment groups (IPO1218) are all IPOs and IPOs $>12 \& \leq 14$ months preceding the event day.

\begin{tabular}{|c|c|c|c|}
\hline & & \multicolumn{2}{|c|}{ Dependent Variable } \\
\hline Date & Events & $A \boldsymbol{V}$ & RETURN \\
\hline $6 / 10$ & Conference committee begins & -0.01 & -0.39 \\
\hline $6 / 11$ & & 0.09 & -0.24 \\
\hline $6 / 12$ & & -0.00 & 0.11 \\
\hline $6 / 15$ & Lott wants change & 0.06 & 0.51 \\
\hline $6 / 16$ & Gingrich predicts later change & 0.16 & 0.60 \\
\hline $6 / 17$ & Tax Notes reports Gingrich comment & 0.08 & -0.48 \\
\hline $6 / 18$ & & 0.14 & 0.51 \\
\hline $6 / 19$ & & 0.16 & -0.27 \\
\hline $6 / 22$ & & $0.34 *$ & 0.62 \\
\hline $6 / 23$ & AP reports change at 6:00 p.m. & 0.23 & 0.78 \\
\hline $6 / 24$ & Conference report released & $0.32 *$ & $-1.07 *$ \\
\hline $6 / 25$ & House passage & $0.31 *$ & $0.89 *$ \\
\hline $6 / 26$ & & 0.14 & 0.21 \\
\hline $6 / 29$ & & 0.20 & 0.15 \\
\hline $6 / 30$ & & 0.11 & 0.34 \\
\hline $7 / 1$ & & 0.20 & 0.59 \\
\hline $7 / 2$ & & -0.01 & -0.26 \\
\hline $7 / 6$ & & 0.05 & -0.54 \\
\hline $7 / 7$ & & 0.10 & 0.02 \\
\hline $7 / 8$ & Senate passage & 0.10 & -0.56 \\
\hline $7 / 9$ & & -0.03 & 0.51 \\
\hline $7 / 10$ & & -0.01 & -0.22 \\
\hline $7 / 13$ & & -0.08 & 0.12 \\
\hline $7 / 14$ & & 0.08 & 0.18 \\
\hline $7 / 15$ & & 0.10 & -0.15 \\
\hline $7 / 16$ & & 0.07 & 0.78 \\
\hline $7 / 17$ & & 0.07 & -0.67 \\
\hline $7 / 20$ & & 0.17 & 0.20 \\
\hline $7 / 21$ & & 0.11 & -0.25 \\
\hline $7 / 22$ & Change becomes law & -0.02 & $0.94^{*}$ \\
\hline
\end{tabular}

* $\quad$ significant at 0.05 level (two-tailed test)

${ }^{\text {a }} H 1218_{\text {it }}$ is a categorical variable equaling one if firm i's IPO occurred between 12 months to 18 months before day under analysis (e.g., June 5, 1998 in the first row of results) and zero otherwise; $D A Y_{t}$ is a categorical variable equaling one if trading day $\mathrm{t}$ is the day under analysis (e.g., June 5, 1998 in the first row of results) and zero otherwise. See Table 1 for other variable descriptions. 